\title{
OXALIPLATIN INDUCED PULMONARY FIBROSIS: A CASE REPORT
}

\author{
Mirjana Pavlović, Robert Šeparović, Tajana Silovski, Ana Tečić Vuger and Andreja Jurić \\ Sestre milosrdnice University Hospital Centre, University Hospital for Tumors, \\ Department of Medical Oncology, Zagreb, Croatia
}

\begin{abstract}
SUMMARY - Oxaliplatin is part of the standard chemotherapy regimens for treating colorectal carcinoma. Pulmonary fibrosis is a serious but rare side effect of oxaliplatin treatment, which resulted in patient death in more than half of the reported cases. The precise pathophysiological mechanism of this phenomenon has not been clarified yet. Analysis of the reported cases strongly suggests that early diagnosis and immediate corticosteroid treatment are crucial for better prognosis. Here we report a case of pulmonary fibrosis related to the FOLFOX regimen in a patient with early colorectal carcinoma.
\end{abstract}

Key words: Oxaliplatin; Colon cancer; Side effects; Pulmonary fibrosis; Interstitial lung disease

\section{Introduction}

Oxaliplatin is a third-generation platin derivative which is frequently used as part of chemotherapeutic regimen for early and advanced colorectal carcinoma. Clinical studies suggest that its toxicity profile includes mainly peripheral sensory neuropathy, gastrointestinal and hematologic toxicity without mentioning pulmonary side effects, so understanding it is based mostly on reported cases. Here we report a case of pulmonary fibrosis related to FOLFOX usage in a patient with early colorectal cancer.

\section{Case Report}

A 66-year-old patient underwent left sided hemicolectomy for splenic flexure colon cancer and consecutively Hartmann operation due to dehiscence of the intestinal anastomosis. The patient was referred to our hospital to receive complementary treatment. He

Correspondence to: Mirjana Pavlovic, MD, Sestre milosrdnice University Hospital Centre, University Hospital for Tumors, Department of Medical Oncology, Ilica 197, HR-10000 Zagreb, Croatia

E-mail: mirjanapavlovic@yahoo.com

Received April 13, 2016, accepted October 9, 2018 had a smoking history of 20 pack-years, and no history of toxic inhalant exposure, hypertension, diabetes mellitus or prior pulmonary disease. Considering histopathologic features of the tumor and results of preoperative radiological workup, our multidisciplinary team decided to start patient treatment with adjuvant oxaliplatin-based FOLFOX regimen every 2 weeks for 6 months, with oxaliplatin at $85 \mathrm{mg} / \mathrm{m}^{2}$. During the first ten cycles of chemotherapy, the patient reported no significant side effects (grade I peripheral neuropathy). Eleventh cycle of chemotherapy had to be discontinued before completion because the patient developed fever (up to $38.5^{\circ} \mathrm{C}$ ) with increased inflammatory parameters but without confirmed site of infection, so he was discharged with broad spectrum antibiotic therapy. At admission to the hospital two weeks later, the patient presented with progressive intolerance of physical activity and dyspnea. Physical examination revealed prolonged expiration with bibasilar inspiratory crackles and arterial blood gas analysis on room air showed partial respiratory insufficiency with $\mathrm{pO}_{2}$ of $8.92 \mathrm{kPa}$, while laboratory findings showed only slightly elevated inflammatory parameters. Multi-slice computed tomography of the thorax showed mediastinal lymphadenopathy with enlarged precarinal and pretracheal lymph nodes, widespread reticular intersti- 


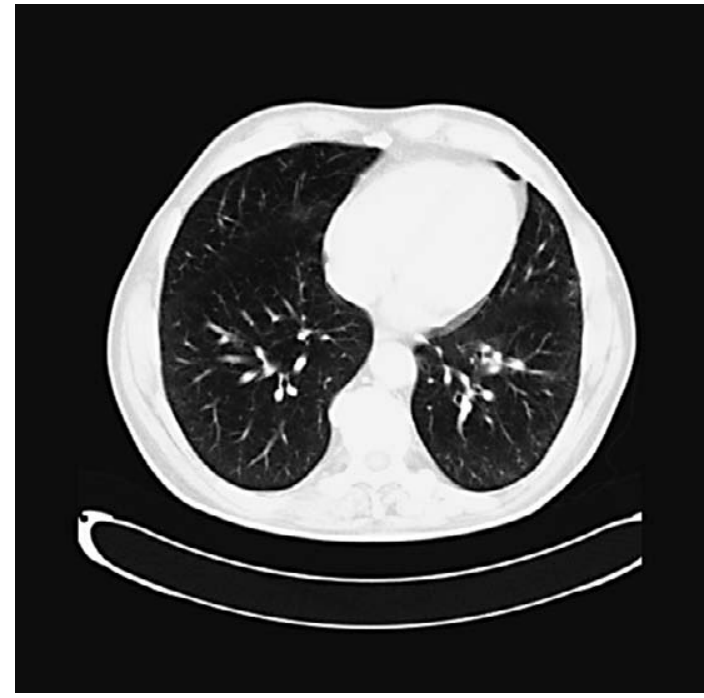

Fig. 1. Computed tomography scan performed after 6 cycles of adjuvant FOLFOX therapy showing normal finding.

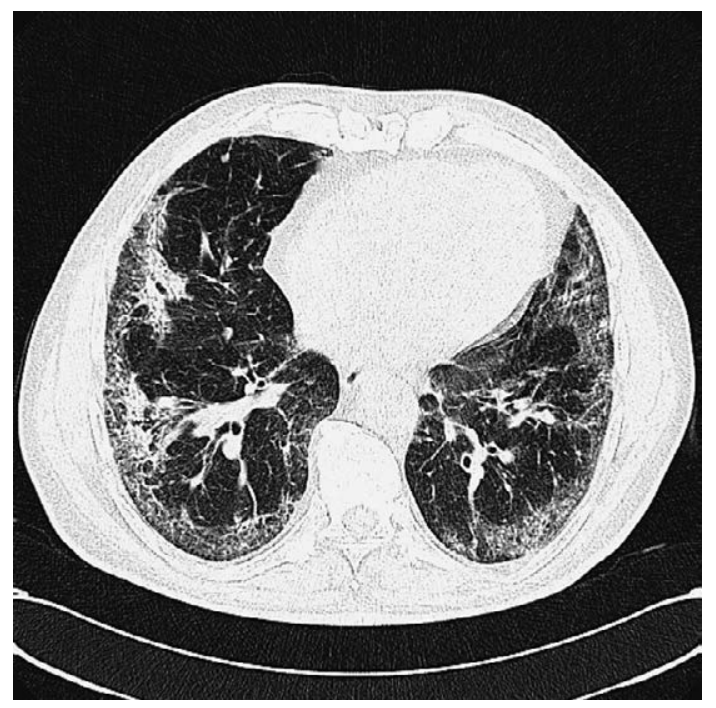

Fig. 2. Computed tomography scan performed after 11 cycles of FOLFOX therapy showing interstitial lung disease with signs of incipient pulmonary fibrosis.

tial pattern with ground-glass opacities, and honeycombing in posterobasal segments of the lower lobes, which implied incipient fibrosis, none described in previous findings (Figs. 1 and 2). Based on the results of the diagnostic workup performed, the patient was diagnosed with interstitial lung disease (ILD) which was, considering the course of the disease, most likely caused by the use of oxaliplatin. High-dose intrave-

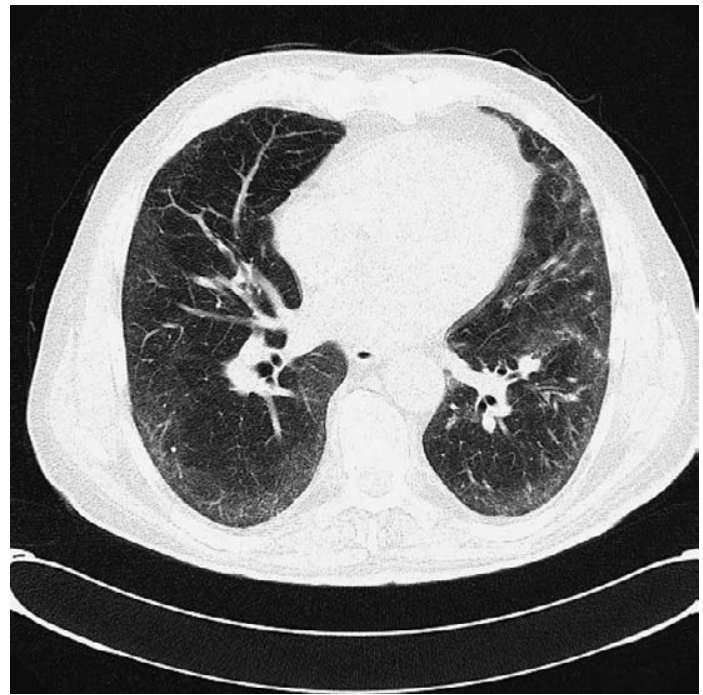

Fig. 3. Computed tomography scan performed two months after initiation of corticosteroid therapy showing regression of pulmonary interstitial infiltrates.

nous corticosteroid therapy was started immediately and the patient was transferred to the pulmonary ward. Additional diagnostics included heart ultrasound that showed pulmonary hypertension of $38-40 \mathrm{~mm} \mathrm{Hg}$; 6-minute walk test showed significant decrease in saturation after exercise; the patient reported severe dyspnea during fiberoptic bronchoscopy, so examination could not be completed; chest radiogram showed interstitial infiltrates in the left upper lobe, right lower lobe and by the inner side of the thoracic wall bilaterally. The patient was discharged home after 10 days with oral corticosteroid therapy (prednisone $30 \mathrm{mg}$ ). In the next few weeks, the patient's condition improved, his computed tomography finding showed regression of pulmonary interstitial infiltrates, and the dose of corticosteroid therapy was gradually decreased (Fig. 3).

\section{Discussion}

The use of oxaliplatin in clinical practice started in $2000^{1}$. At the University Hospital for Tumors, we started using oxaliplatin 7 years ago and in the last two years we treated a total of 168 patients. Oxaliplatin was mostly used as part of FOLFOX regimen for metastatic colorectal cancer and less frequently in patients with early colorectal cancer and patients with advanced gastric or pancreatic cancer. The most frequently re- 
ported side effects in phase III clinical trials include peripheral sensory neuropathy, hematologic and gastrointestinal toxicity, allergic reactions, and fatigue ${ }^{2}$. According to the Croatian Agency for Medicinal Products and Medical Devices (HALMED), the most reported side effects of oxaliplatin in Croatia were those classified as very common and common in product safety profile, such as nervous system disorders (peripheral sensory neuropathy), gastrointestinal disorders (diarrhea, abdominal pain), vascular disorders (increased blood pressure), and skin disorders (rash, hyperhidrosis). To date, visual disturbance (blurred vision) was reported as a rare side effect of oxaliplatin in only one patient. The case presented is the first case of pulmonary toxicity related to oxaliplatin use ever noted at the University Hospital for Tumors and the only case ever reported in Croatia according to the available HALMED data. Homma et al. report on the $0.2 \%$ incidence of oxaliplatin induced pulmonary toxicity in Japan in 2007, which is consistent with the incidence reported in product safety profile (pulmonary toxicity is graded as a rare side effect that occurs in $<1: 1000$ and $>1: 10000$ cases) $)^{3}$. A recently published literature review has listed 28 cases of pulmonary toxicity related to oxaliplatin use in the form of ILD and pulmonary fibrosis, and 16 of them resulted in patient death. The authors believe that the actual incidence of this side effect is probably higher, but milder cases remain unrecognized or are not being reported enough. Analysis of all reported cases showed that the vast majority of patients were men older than 60 years, without preexisting lung disease $(77 \%, 92.3 \%$ and $73 \%$, respectively); $27 \%$ of the patients described had pre-existing lung disease, $8 \%$ were smokers, and $15 \%$ of them had arterial hypertension; ten patients received oxaliplatin in adjuvant setting, and seven of them died from pulmonary disease ${ }^{4}$. The exact pathogenesis of FOLFOXinduced interstitial pneumonia is unknown. It is assumed that oxaliplatin induces secondary depletion of glutathione, a molecule that prevents oxidative damage to important cellular components in different organs ${ }^{5}$. One case exhibited good response to $\mathrm{N}$-acetylcysteine therapy, which is used as a means of glutathione repletion $^{6}$. Other presumed pathogenetic mechanisms include cytotoxic and immune mechanisms. The cytotoxic mechanism implies direct effect of the drug and/ or its metabolites on lung cell components and is usually dose-dependent, while the immune mechanisms can include type I (anaphylactic reaction) or type IV (late allergic reaction) hypersensitivity reactions ${ }^{3,7}$. It is interesting to mention the attempts of treatment with imatinib, where imatinib was identified as a potent inhibitor of lung fibroblast-myofibroblast transformation and proliferation, and extracellular matrix production through inhibition of platelet-derived growth factor and transforming growth factor- $\beta$ signaling. Treatment with imatinib showed benefit in patients with interstitial lung disease, systemic sclerosis and mixed connective tissue disease, although results of a randomized double-blind, placebo-controlled study in 119 patients with interstitial lung disease treated with imatinib or placebo for 96 weeks showed no difference in overall survival and time to disease progression between groups ${ }^{8-11}$. Although there is a small number of reported cases of oxaliplatin induced ILD and it is difficult to draw any firm conclusion from the given data, comparison of characteristics of survivors and deceased patients showed that early diagnosis and early start of treatment is crucial for better prognosis. Discontinuation of the culprit agent and systemic corticosteroids have been widely accepted as therapy for drug-induced ILD, although there are no randomized controlled trials to confirm its effectiveness ${ }^{12}$.

Pulmonary complications of chemotherapeutics are under-recognized and thus under-reported. Early recognition is of great importance because it allows prompt cessation of chemotherapy and initiation of systemic corticosteroids, which can significantly improve patient outcome. It is particularly important to keep in mind the possibility of this severe side effect in patients treated with oxaliplatin in the adjuvant setting.

\section{References}

1. De Gramont A, Figer A, Seymour M, Homerin M, Hmissi A, Cassidy J, et al. Leucovorin and fluorouracil with or without oxaliplatin as first-line treatment in advanced colorectal cancer. J Clin Oncol. 2000 Aug;18(16):2938-47. doi: 10.1200/ JCO.2000.18.16.2938.

2. Ramanathan RK, Clark JW, Kemeny NE, Lenz HJ, Gococo $\mathrm{KO}$, Haller DG, et al. Safety and toxicity analysis of oxaliplatin combined with fluorouracil or as a single agent in patients with previously treated advanced colorectal cancer. J Clin Oncol. 2003 Aug 1;21(15):2904-11. doi: 10.1200/JCO.2003.11.045.

3. Homma T, Kurokawa M, Yamamoto Y, Matsukura S, Ieki K, Suzuki S. Oxaliplatin-induced lung injury with allergic reaction. Chin J Cancer Res. 2011 Sep; 23(3):232-5. doi: 10.1007/ s11670-011-0232-y. 
4. Moskowitz M, Wollner M, Haim N. Oxaliplatin-induced pulmonary toxicity in gastrointestinal malignancies: two case reports and review of the literature. Case Rep Oncol Med. 2015;2015:341064. doi: 10.1155/2015/341064.

5. Kinnula VL, Vuorinen K, Ilumets H, Rytila P, Myllarniemi M. Thiol proteins, redox modulation and parenchymal lung disease. Curr Med Chem. 2007;14:213-22. https://doi.org/ 10.2174/092986707779313345.

6. Wilcox BE, Ryu JH, Kalra S. Exacerbation of pre-existing interstitial lung disease after oxaliplatin therapy: a report of three cases. Respir Med. 2008;102:273-9. https://doi.org/10.1016/j. rmed.2007.09.001.

7. Makrilia N, Syrigou E, Kaklamanos I, Manolopoulos L, Saif MW. Hypersensitivity reactions associated with platinum antineoplastic agents: a systematic review. Met Based Drugs. 2010;2010:207084. doi: 10.1155/2010/207084.

8. Daniels CE, Wilkes MC, Edens M, Kottom TJ, Murphy SJ, Limper AH, et al. Imatinib mesylate inhibits the profibrogenic activity of TGF-beta and prevents bleomycin-mediated lung fibrosis. J Clin Invest. 2004 Nov;114(9):1308-16. doi: 10.1172/ JCI19603.

9. Sfikakis PP, Gorgoulis VG, Katsiari CG, Evangelou K, Kostopoulos $\mathrm{C}$, Black CM. Imatinib for the treatment of refractory diffuse systemic sclerosis. Rheumatology. 2008;47(5):735-7. doi: 10.1093/rheumatology/ken104.

10. Distler JH, Manger B, Spriewald BM, Schett G, Distler O. Treatment of pulmonary fibrosis for twenty weeks with imatinib mesylate in a patient with mixed connective tissue disease. Arthritis Rheum. 2008;58(8):2538-42. doi: 10.1002/art.23694.

11. Daniels CE, Lasky JA, Limper AH, Mieras K, Gabor E, Schroeder DR. Imatinib treatment for idiopathic pulmonary fibrosis: randomized placebo-controlled trial results. Am J Respir Crit Care Med. 2010 Mar 15;181(6):604-10. doi: 10.1164/rccm.200906-0964OC.

12. Vahid B, Marik PE. Pulmonary complications of novel antineoplastic agents for solid tumors. Chest. 2008;133:528-38. https://doi.org/10.1378/chest.07-0851.

Sažetak

\title{
PLUĆNA FIBROZA IZAZVANA OKSALIPLATINOM: PRIKAZ SLUČAJA
}

\author{
M. Pavlović, R. Šeparović, T. Silovski, A. Tečić Vuger i A. Jurić
}

Oksaliplatin je dio standardnih kemoterapijskih protokola za liječenje kolorektalnog karcinoma. Plućna fibroza je ozbiljna, ali rijetka nuspojava primjene oksaliplatina, koja je rezultirala smrću bolesnika u više od polovine prijavljenih slučajeva. Točan patofiziološki mehanizam nastanka ove nuspojave još nije u potpunosti razjašnjen. Analiza prijavljenih slučajeva je pokazala da su rana dijagnoza i rani početak liječenja kortikosteroidima od ključne važnosti za bolju prognozu. Ovdje prikazujemo slučaj plućne fibroze uz primjenu oksaliplatina u bolesnika s ranim kolorektalnim karcinomom.

Key words: Oksaliplatin; Karcinom kolona; Nuspojave; Plućna fibroza; Intersticijska plućna bolest 